\title{
A Multidimensional Evaluation of the Sustainable Development of European Union Countries - An Empirical Study
}

\section{- Dana Kiselakova, Matgorzata Stec, Mariola Grzebyk, Beata Sofrankova}

\begin{abstract}
The main aim of this research paper is to compare the total synthetic measure value of sustainable development for each EU country using a multidimensional comparative analysis of the EU countries in terms of sustainable development. The statistical evaluation of this complex phenomenon was based on 108 statistical indicators describing 17 goals of sustainable development which were taken from the Eurostat database. The statistical data applies mostly to the year 2018. The zero unitarization method was applied as a research tool. Passing through consecutive stages, the values of synthetic measures with variables determining the subsequent goals of sustainable development were set. Our study led to the ranking of EU countries into groups of high, medium-high, medium-low and low level of sustainable development. The results confirmed that the leaders of sustainable development in the EU are Sweden, Denmark, Finland and Austria. Most EU countries have reached the medium level, while Romania, Bulgaria, Greece and Cyprus have poorly realized the goals of sustainable development. Due to the growing importance of countries of the Visegrad group in Europe, this article also subjected them to a more detailed assessment in terms of their sustainable development. Among the Visegrad countries, only the Czech Republic has reached a medium-high level of sustainable development. The other three countries, i. e. Hungary, Poland and Slovakia, hold a similar position in the ranking of EU countries in terms of sustainable development. Considering future generations, the implementation of the goals of sustainable development as well as the identification of key indicators for each country are becoming an important challenge in terms of global market competitiveness.
\end{abstract}

Keywords: sustainable development, challenges to sustainable competitiveness, a multidimensional comparative analysis, synthetic measure

JEL Classification: C80, C82, 011

Received: March, 2020

1st Revision: November, 2020

Accepted: November, 2020

\section{INTRODUCTION}

For years, European Union countries have been striving to transform the EU economy into the most competitive knowledge-based economy in the world. Hence, one of the main goals of the 
EU is to implement policies of sustainable development (Barbier \& Burgess, 2019; Płachciak, 2010; Rhouma, 2010; Ulewicz \& Blaskova, 2018).

Sustainable development (SD) is a very popular term, one widely used in scientific literature, legal acts as well as strategic documents. Although at first glance the concept might seem to be quite comprehensible, a specific definition and interpretation of the term has provoked broad debate among theoreticians as well as practitioners (Boons et al., 2013, Gong et al., 2018; Mikušová, 2017).

The terms sustainability and sustainable development have been embraced by big business, governments, social reformers and environmental activists, all of which put their own interpretation on what these concepts mean (Busłowska, 2014; Sutopo, et al., 2018). The most universal and synthetic approach to sustainable development describes it in terms of uniting goals related to economic strength, ecologic soundness and social acceptability (Barbier, 2016; Zielińska, 2011). $\mathrm{SD}$ is a compromise between environmental, economic and social goals which constitute the welfare of the contemporary and future generations. The economic aspect indicates not only the satisfaction of present needs, but also securing resources required for needs of future generations (natural, material, intellectual and social capital). The ecologic aspect means the establishment of borders of ecologic environment for human activity which should not be crossed. The social aspect is identified with education and an ability to resolve fundamental social issues, as well as participation by all in the development processes of the whole system (Ciegis et al., 2009a; Cyrek \& Fura, 2019; Marková et al., 2017; Škare et al., 2013).

The most important shared features included in various definitions of SD are interactions between economic, ecologic, demographic and social development factors, the necessity for predictions and analyses of the influence on present decisions on the quality of life for future generations, distributive justice, and emphasizing the non-material aspects of quality of life in welfare shaping (Elliott, 2006; Zakrzewska, 2019). The primary goal of sustainable development to increase the sustainable competitiveness of economies, which can only be rational when these systems deal with underlying social problems such as poverty, education and employment, as well as environmental problems, i.e. pollution, greenhouse gas emissions, renewable energy, etc. to create the best possible living conditions for societies (Cheba, 2019; Lapinskiene, 2011; Popescu et al., 2017).

With knowledge advances in terms of the goals of sustainable development come reflections and critical analyses of the putative achievements towards its ends. The fundamental ambiguities in defining SD due to its multidimensional and interdisciplinary character along with the great liberties researchers have taken in construing concrete metrics regarding sustainable development present huge challenges. On the other hand, the lack of a consistent or practical definition for sustainable development may contain a hidden positive element in terms of the scope and latitude many researchers perceive in studying this field (Meadowcroft, 2007).

The EU has advanced in implementing the ambiguous paradigm of sustainable development. Therefore, monitoring certain relevant changes in these countries with the help of specially chosen indicators takes on great meaning. The task is to clearly show the past and future developments in achieving the goals of SD (Cheba \& Szopik-Depczyńska, 2017; Fura \& Wang, 2017; 
Grzebyk \& Stec, 2015; Kološta et al., 2019; Momete, 2016; Stec et al., 2014; Steuner \& Hametner, 2013).

Due to the complexity related to the very meaning of sustainable development, comparisons of the level as well as evaluations of each European Union country in implementing its goals is quite a difficult and time-consuming task, especially due to the fact the number and scope of the goals continue to expand. This task requires the specification of a measurement mode as well as precise metrics for this type of survey (Mashokhida et al., 2018). Due to the lack of one generally accepted measure, the authors attempted to operationalize the level of achievement of sustainable development goals in a synthetic way. We sought to determine the general total sum of the measure in a comprehensive way, especially due to the fact that the indices of the strategic document Europe 2020 is coming to an end. We hope that our research will be a basis for further deliberations and analyses in this field. By joining the research stream on sustainable development, we would like to present the level of achievement with regard to 17 new development goals in each EU country through a comprehensive approach, and classify them according to a designed synthetic measure.

The paper is organized as follows. In the first and second part of the article, the origin of the concept of sustainable development linked to competitiveness in Europe is presented, with special attention devoted to the achievements of conferences on this topic. The difficulty in operationalizing the level of sustainable development was a very important aspect emphasized in the research. All the methodological steps toward formulating a synthetic measure of sustainable development were presented in relation to this aspect in part 3. By employing 108 partial variables (covering the year 2018 and previous years in cases of a lack of data), the authors ranked the EU countries in terms of value of sustainable development synthetic measure in a cross-section of the described goals of sustainable development as well as in general terms. An important element of analysis was to cluster the EU countries and define groups in terms of high, medium-high, medium-low and low level of sustainable development, which was undertaken in part 4 . In the last part, the results are summarized, with recommendations provided.

\section{SUSTAINABLE DEVELOPMENT IN THE EUROPEAN UNION}

Assumptions regarding the concept of SD have been recognized as fundamental in the development process of all EU member states. These serve as a natural basis for solutions implemented by the European Union regardless of whether we are dealing with the planning, preparation or implementation phase (The EU, 2016).

The arrangements made at the Rio Summit in 1992 coincided with the work on the Maastricht and Amsterdam Treaties, all of which had a major impact on shaping the EU at its very outset. The Maastricht Treaty later in 1992 clearly underlines the importance of sustainable development for the Union. This assumption soon went beyond the provisions of the most important treaty documents, a result evidenced by the fact that the Environmental Action Programme implemented in the years 1992-2000 clearly signaled the goal of the European Union activities in this area even in its very title On the Road to Sustainability. 
The Treaty of Amsterdam in 1997 strongly emphasized the relationship between sustainability and environmental protection. Other important program documents that have developed or supplemented the assumptions of sustainable development adopted by the EU are the Lisbon Strategy (2002) and the Gothenburg Strategy (Sustainable development in the EU, 2017).

The EU updated the Sustainable Development Strategy in 2006 under the name SDS. In the light of the provisions of this document, the policy goal of the EU countries is to continually improve the quality of life of citizens through the establishment of communities that respect the principle of sustainable development, manage resources and use them effectively, as well as use economic potential related to ecological and social innovation, ensuring prosperity, environmental protection and social coherence. Any legislative proposal of an undertaken or abandoned action was to include a description of the potential economic, environmental and social impacts (Simionescu et al., 2017). Taking into account the changing economic reality along with Europe's strengths and weaknesses, the EU commission launched the new strategy Europe 2020 in March 2010, which was released as the follow up to the Lisbon strategy. Europe 2020 puts forward three mutually reinforcing priorities: smart (developing an economy based on knowledge and innovation), sustainable (promoting a more resource- efficient, greener and more competitive economy), and inclusive (fostering a high-employment economy delivering social and territorial cohesion) growth (European Commission, 2016). Both Lisbon and Europe 2020 contain policies compelling European Union countries to increase competitiveness as well as maintain sustainable development (Dobrovic et al., 2018).

In addition to strategic documents stating a certain general direction, there are also more detailed references to the Union sustainable development, which represent the content of various categories of documents or initiatives (Wskaźniki, 2011): White Papers - function as political declarations regarding specific areas of common EU policy; Green Papers - refer to specific sectors of integration, can be a starting point for the development of a White Paper; Communications from the European Commission, Opinions provided by the European Economic and Social Committee.

The repeated definition of sustainable development in these documents, referring to "building a sustainable and competitive resource-efficient economy", is the basis on which the proposals for European activities in strengthening its position have been created and developed. These actions include increasing the EU competitiveness, fighting climate changes and cleaner, more efficient energy.

The EU competitiveness is based mainly on the import and export of products and raw materials worldwide. Europe, however, notes the threat of increasing competitive pressure, especially from China and North America. The aim of sustainable development is to increase competitiveness by increasing efficiency and maintaining a leading position in the markets for environmentally friendly technologies. As a consequence, this is to ensure the efficient use of resources and the removal of infrastructural obstacles (Balkyte \& Tvaronavičienè, 2010).

However, the existence of 17 instead of 8 goals in the Agenda for SD-2030 makes it difficult to assess their progress (Colglazier, 2015; Kološta et al., 2019). The new agenda is largely in line with the Union approach as expressed in recent strategies: Agenda for Change (2011) and A Decent 
Life for All (2013). The EU Council conclusions of December 2014 and May 2015 set the goals and values for a new global partnership, calling for a paradigm shift in favor of a universal, inclusive and inspiring agenda covering three dimensions: social, economic and environmental. The Union also sought to add climate issues explicitly to new targets and to take into account the importance of developing good governance, the rule of law and human rights. In addition, it stresses the importance to improving policy coherence, better coordination and transparency of help.

The imperative goal of the EU strives for territorial cohesion, while the implementation of sustainable development assumptions will require the selection of appropriate tools and sets of indicators describing the level and dynamics of changes in scope. Therefore, the authors have attempted to show the state of sustainable development for each EU country via synthetic approach, taking into account all 17 goals, but not analyzing each goal individually.

\section{RESEARCH OBJECTIVES, METHODOLOGY AND DATA OF THE SUSTAINABLE DEVELOPMENT CONCEPT}

In the international literature, one can find attempts to operationalize the level of sustainable development of various countries in the world. Difficulties in measuring sustainable development arise from the diversity of definitions and determinants of this development.

The lack of agreement among researchers regarding the importance of individual plans creating sustainable development results in many ways of measuring this phenomenon (Taylor, 2014).

The selection of indicators that allow measuring the implementation of the concept of sustainable development is the subject of constant discussion. They are to answer the question to what extent development in the studied case corresponds to this idea. However, the use of sustainable development indicators usually aims to illustrate the degree of implementation of the principles and individual goals adopted in the SDS (Bartłomowicz \& Cheba, 2017; Borys, 2011).

The main aim of this research was to compare the overall synthetic measure value of sustainable development for each EU country. The EU countries were ordered in terms of level of sustainable development. Positions of Visegrad Group countries among the EU-28 were also determined.

This article attempts to answer the following research tasks and objectives:

1. The EU countries have a diversified level in terms of sustainable development using the synthetic measures; its assumptions are best fulfilled by the EU-15 countries.

2. The Visegrad Group countries have taken a similar position in the ranking of the EU countries in terms of sustainable development.

This article, in the multidimensional comparative research on sustainable development of the EU countries, includes a total of 108 variables defining 17 of its objectives. The variables defining Goal 6 and Goal 14 were not included in the study due to the lack of data for all EU countries (our research limitations). The number of variables (depending on a purpose) ranged from 4 to 10 variables. Statistical indicators were taken from the Eurostat database (Table 1). 
Tab. 1 - Sustainable development goals according to the Agenda for Sustainable Development - 2030. Source: own research

\begin{tabular}{|c|c|c|}
\hline $\begin{array}{l}\text { Goal's } \\
\text { number }\end{array}$ & Goal name & $\begin{array}{l}\text { Number of } \\
\text { variables }\end{array}$ \\
\hline Goal 1 & End poverty in all its forms everywhere & 9 \\
\hline Goal 2 & $\begin{array}{l}\text { End hunger, achieve food security and improved nutrition and } \\
\text { promote sustainable agriculture }\end{array}$ & 6 \\
\hline Goal 3 & Ensure healthy lives and promote well-being for all at all ages & 10 \\
\hline Goal 4 & $\begin{array}{l}\text { Ensure inclusive and equitable quality education and promote } \\
\text { lifelong learning opportunities for all }\end{array}$ & 7 \\
\hline Goal 5 & Achieve gender equality and empower all women and girls & 9 \\
\hline Goal 6 & $\begin{array}{l}\text { Ensure availability and sustainable management of water and } \\
\text { sanitation for all }\end{array}$ & No data \\
\hline Goal 7 & $\begin{array}{l}\text { Ensure access to affordable, reliable, sustainable and modern } \\
\text { energy for all }\end{array}$ & 8 \\
\hline Goal 8 & $\begin{array}{l}\text { Promote sustained, inclusive and sustainable economic growth, } \\
\text { full and productive employment and decent work for all }\end{array}$ & 9 \\
\hline Goal 9 & $\begin{array}{l}\text { Build resilient infrastructure, promote inclusive and sustainable } \\
\text { industrialization and foster innovation }\end{array}$ & 6 \\
\hline Goal 10 & Reduce inequality within and among countries & 7 \\
\hline Goal 11 & $\begin{array}{l}\text { Make cities and human settlements inclusive, safe, resilient and } \\
\text { sustainable }\end{array}$ & 8 \\
\hline Goal 12 & Ensure sustainable consumption and production patterns & 7 \\
\hline Goal 13 & Take urgent action to combat climate change and its impacts & 6 \\
\hline Goal 14 & $\begin{array}{l}\text { Conserve and sustainably use the oceans, seas and marine } \\
\text { resources for sustainable development }\end{array}$ & No data \\
\hline Goal 15 & $\begin{array}{l}\text { Protect, restore and promote sustainable use of terrestrial } \\
\text { ecosystems, sustainably manage forests, combat desertification, } \\
\text { and halt and reverse land degradation and halt biodiversity loss }\end{array}$ & 5 \\
\hline Goal 16 & $\begin{array}{l}\text { Promote peaceful and inclusive societies for sustainable devel- } \\
\text { opment, provide access to justice for all and build effective, } \\
\text { accountable and inclusive institutions at all levels }\end{array}$ & 7 \\
\hline Goal 17 & $\begin{array}{l}\text { Strengthen the means of implementation and revitalize the } \\
\text { Global Partnership for Sustainable Development }\end{array}$ & 4 \\
\hline
\end{tabular}

Statistical evaluation of the level of sustainable development of the European Union countries was carried out using the zero unitarization method (ZUM) (Kukuła \& Bogocz, 2014; Balcerzak, 2015), belonging to the group of methods called the multidimensional comparative analysis. The choice of this method among many methods of linear ordering of objects was determined by the fact that it is an internationally accepted way of bringing variables to comparability. It was used, for example, as part of the Human Development Index (HDI) calculation methodology 
(Hollanders, 2019) and, for example, in determining the Summary Innovation Index of the EU countries. It can also be seen that the zero unitarization method is quite often used in the assessment of the so-called complex phenomena, i. e. those that cannot be described with one indicator. It allows to determine the value of synthetic (aggregate) measure (SM) on the basis of partial information contained in many variables. Based on the value of a synthetic measure, objects can be ordered from the best to the worst in terms of the studied complex phenomenon, i. e. the level of sustainable development - the problem raised in the article. Such a comprehensive approach allows to set a hierarchy of countries due to the level of sustainable development and to indicate similar countries from a point of view of the level of analyzed phenomenon.

The methodology consists of a few steps:

1. Presentation of values of variables in the form of an observation matrix:

$\mathbf{X}=\left[\begin{array}{rrrr}x_{11} & x_{12} & \Lambda & x_{1 m} \\ x_{21} & x_{22} & \Lambda & x_{2 m} \\ \mathrm{M} & \mathrm{M} & \mathrm{M} & \mathrm{M} \\ x_{n 1} & x_{n 2} & \Lambda & x_{n m}\end{array}\right]$

where:

$x_{i j}$ - the value of the variable $X_{j}(j=1,2, \ldots, m)$ in the object $O_{i}(i=1,2, \ldots, n)$,

2. Bringing variables to comparability, using an appropriate (depending on the nature of the variable) normalization method:

$Z_{i j}=\frac{x_{i j}-\min _{i}\left\{x_{i j}\right\}}{R_{j}}$

for stimulants

$z_{i j}=\frac{x_{i j}-\min _{i}\left\{x_{i j}\right\}}{R_{j}}$

for destimulants

$z_{i j}=\left\{\begin{array}{l}\frac{x_{i j}-\min _{i}\left\{x_{i j}\right\}}{c_{0 j}-\min _{i}\left\{x_{i j}\right\}} x_{i j}<c_{0 j} \\ 1 x_{i j}=c_{0 j} \\ \frac{\max _{i}\left\{x_{i j}\right\}-x_{i j}}{\max _{i}\left\{x_{i j}\right\}-c_{0 j}} x_{i j}>c_{0 j}\end{array} \quad\right.$ for neutral variables

where: $\mathfrak{\gamma}_{i j}$ - normalized value of $j$-th variable for the $i$-th object, $x_{i j}$ - value of $j$-th variable for the $i$-th object, $R_{j}$ - range for the $j$-th variable, $c_{0 j}$ - nominal value.

Stimulants are variables whose high values are desirable from the assumed point of view, e. g. the level of sustainable development, while the low ones are undesirable. Destimulants are variables whose low values are desirable from a particular point of view, while high values are undesirable. Nominants are variables for which there is an "optimal" level, and both downward and upward deviations are undesirable.

3. Determining the values of synthetic measures, taking into account the variables specifying individual sustainable development goals $\left(S M_{G i}\right)$, according to the formula: 
$S M_{G i}=\frac{1}{m} \sum_{j=1}^{m} z_{i j}$

The synthetic measure takes values from the range [0;1]. The closer to 1 , the higher the level of sustainable development of the object under scrutiny (EU country) in regard to the examined objective.

4. Calculation of the total value of sustainable development synthetic measure $\left(S M_{t i}\right)$ for each individual EU country as an arithmetic mean of synthetic measures determined for individual 15 sustainable development goals. Two objectives, i. e. Goal 6 and Goal 14, were not included due to the lack of data at the level of all countries of the European Union:

$S M_{t i}=1 / 15\left(S M_{G 1}+S M_{G 2}+S M_{G 3}+\Lambda+S M_{G 17}\right)$

This approach has its justification, because each of the individual sustainable development goal makes the same contribution to the final assessment of the level of sustainable development of the EU countries, and also makes it independent of the number of variables defining a given sustainable development goal.

5. Classification of objects into similar four groups in terms of the level of sustainable development according to the scheme:

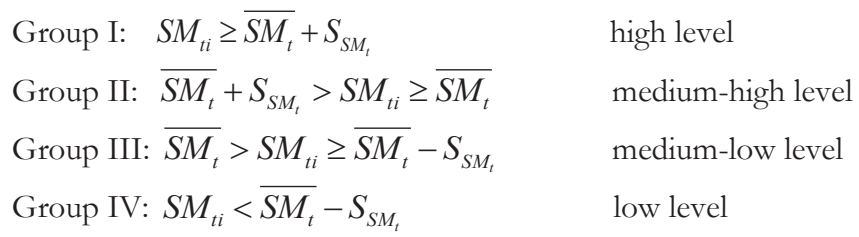

where:

$\overline{S M_{t}}$ - mean value of the total synthetic measure

$S_{S M_{t}}$ - standard deviation of the total synthetic measure.

\section{RESULTS AND DISCUSSION}

Table 2 (see appendix) contains the values of synthetic measures for the EU countries calculated for individual sustainable development goals, in accordance with formula no. 5. Countries classified in group I (with a high level of sustainable development) and group II (with a medium-high level of development) under individual objectives are marked in bold, in accordance with the division diagram/scheme No. 7.

Analyzing the data in Table 2, it can be seen that the obtained values of synthetic measures for the countries of Western and Northern Europe (EU-15) clearly differ from the rest of the EU. In addition, it should be noted that it is these countries that dominate in terms of value of the majority of partial indicators affecting the level of sustainable development. On the other hand, certain EU countries do not stand out regarding the majority of sustainable development goals. These include Bulgaria, Greece, Spain, Croatia, Cyprus, Portugal and Romania. Our article also draws attention to the results of research in the field of sustainable development for the Visegrad 
countries, i. e. the Czech Republic, Hungary, Slovakia and Poland. It should be mentioned that although the Visegrad countries only joined the EU in 2004 and they differ in size and population, this group ranks among one of the fastest growing economic blocks in Europe (Table 3).

Tab. 3 - The most important economic indicators for the Visegrad countries in 2018. Source: own research

\begin{tabular}{|l|l|l|l|l|}
\hline Indicators & Czechia & Hungary & Poland & Slovakia \\
\hline Area in $\mathrm{km}^{2}$ & 78866 & 93030 & 312679 & 490345 \\
\hline Population in millions & 10.7 & 9.7 & 38.2 & 5.45 \\
\hline GDP per capita in USD & 23077 & 15928 & 15250 & 19950 \\
\hline GDP growth rate in \% & 3.0 & 4.9 & 5,1 & 4,1 \\
\hline Unemployment rate in \% & 2.2 & 3.7 & 3.9 & 6.5 \\
\hline
\end{tabular}

The research results regarding the position of the Visegrad countries against the EU in terms of the level of sustainable development are presented in Table 4. An analysis of our results shows that among the V4 countries, the Czech Republic presented a relatively good situation in terms of accomplishing individual sustainable development goals.

The Czech Republic is a leader in terms of Goal 1. (Absence of poverty) and Goal 10. (Reduced inequalities), achieving 1st and 2nd place, respectively, in the entire EU. The Czech Republic placed 6th in terms of reaching Goal 2 (Zero hunger), Goal 8 (Decent work and economic growth) and Goal 11 (Sustainable cities and communities). It also took a strong 8th place in Goal 17 (Partnerships for the goals). The other countries of the Visegrad group, i. e. Hungary, Poland and Slovakia, were usually in the second half of the EU rankings created for most of the sustainable development goals. A relatively high ranking of 8th place went to Hungary only in the case of Goal 11 (Sustainable cities and communities), as was the case of Slovakia for Goal 15 (Life on land).

Tab. 4 - Positions of the Visegrad countries in relation to other EU countries in terms of the value of synthetic measures for purposes of sustainable development. Source: own research

\begin{tabular}{|l|l|l|l|l|l|l|l|l|l|l|l|l|l|l|l|}
\hline Country & \multicolumn{10}{|c|}{ Goal number } \\
\hline & 1 & 2 & 3 & 4 & 5 & 7 & 8 & 9 & 10 & 11 & 12 & 13 & 15 & 16 & 17 \\
\hline Czechia & 1 & 6 & 18 & 17 & 23 & 17 & 6 & 11 & 2 & 6 & 23 & 15 & 13 & 21 & 8 \\
\hline Hungary & 13 & 19 & 19 & 21 & 26 & 19 & 16 & 15 & 16 & 8 & 21 & 11 & 15 & 15 & 18 \\
\hline Poland & 17 & 24 & 22 & 15 & 11 & 16 & 23 & 22 & 19 & 18 & 26 & 24 & 19 & 11 & 24 \\
\hline Slovakia & 10 & 11 & 14 & 23 & 22 & 15 & 21 & 20 & 14 & 9 & 22 & 16 & 8 & 25 & 26 \\
\hline
\end{tabular}

In the next stage of the research, using formula No. 6 the values of the total synthetic measure of sustainable development () were determined for the respective EU countries, with the placing of the Visegrad countries in the constructed ranking determined (Figure 1). 


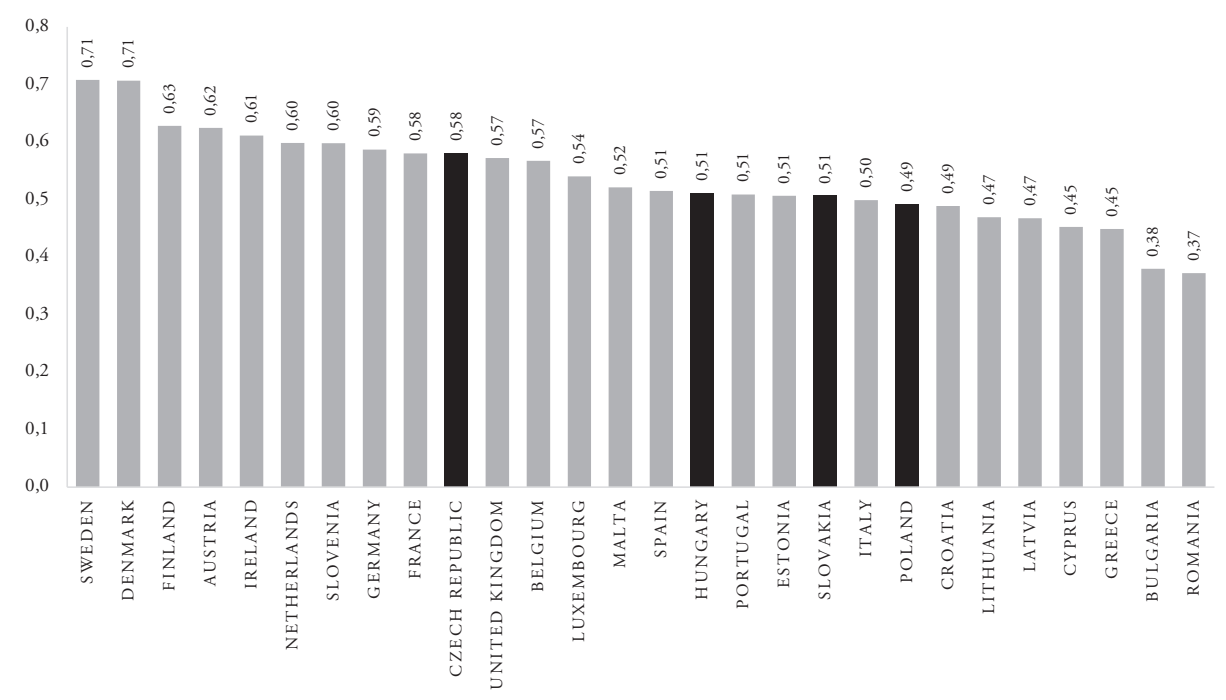

Fig. 1 - Ranking of the EU countries in terms of the value of the total synthetic measure of sustainable development. Source: own research

The data presented in Figure 1 show that Sweden, Denmark, Finland and Austria are leaders in terms of sustainable development with regard to these 15 objectives. Romania, Bulgaria, Greece and Cyprus are in the worst situation. In the EU countries ranking, the Czech Republic, Hungary, Slovakia and Poland took similar positions: 10th, 16th, 19 th and 21st place respectively.

The article also classifies the EU countries into similar groups in terms of the level of sustainable development according to Scheme 7. The results are presented in Figure 2.

A group with a high level of sustainable development was made up of 4 countries, i.e. Sweden, Denmark, Finland and Austria. These countries achieved the most favorable average values for up to 66 output variables determining sustainable development. Nine EU countries have a medium-high level of sustainable development. These are Ireland, the Netherlands, Slovenia, Germany, France, the Czech Republic, the United Kingdom, Belgium and Luxembourg. This group stood out in terms of the average values of 16 sustainable development output variables. On the other hand, the medium-low level was found in 11 EU countries: Malta, Spain, Hungary, Portugal, Estonia, Slovakia, Italy, Poland, Croatia, Lithuania and Latvia. In this group, the average values of 10 output variables of sustainable development turned out to be the most favorable. Four EU countries, i.e. Cyprus, Greece, Bulgaria and Romania, are included in the group of countries with a low level of sustainable development. The number of output variables with the most favorable average values in this group of countries was 16, but this did not improve their position in the European ranking.

The results of the research obtained by the authors confirm that there are countries clearly different from the other countries being part of the EU in terms of the achieved level of sustainable development. These include Sweden, Finland, Denmark and Austria - leaders. The second group includes those located in Western Europe, which is Ireland, United Kingdom, Netherlands, Bel- 
gium, Germany, Luxembourg, France and only one country from Central and Eastern Europe, which is the Czech Republic. These countries (except for the Czech Republic) are members of the EU-15 and properly implement the concept of sustainable development. However, several countries from this group, i.e. Greece, Italy, Portugal and Spain, have evident problems in this aspect as they were classified into medium and low sustainability classes.

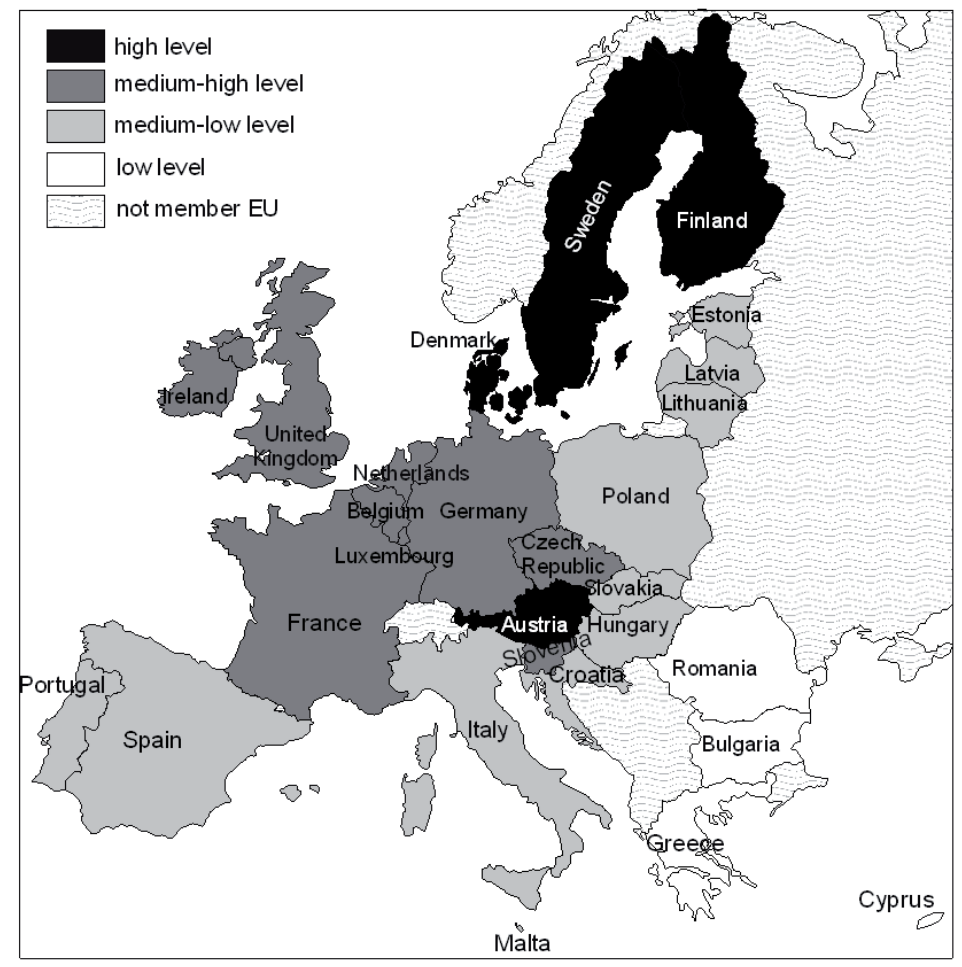

Fig. 2 - Classification of the EU countries into groups with a similar level of sustainable development total synthetic measure. Source: own research

The results of the conducted research confirmed the diversified level of sustainable development in the EU countries and the fact that its assumptions are best met by the EU-15 countries (the results of the research objective 1).

Among the countries of the Visegrad group, only the Czech Republic achieved a medium-high level of sustainable development, taking 10th place in the overall ranking of EU countries. Hungary, Poland and Slovakia each reached a similar, medium-low level of sustainable development, taking the 16th, 21th and 19th position, respectively. A number of differences among these countries occur with regard to the implementation of the concept of sustainable development across each country's individual goals (the results of the research objective 2).

Similar results regarding the assessment of the level of sustainable development of EU countries are presented in a study by Cheba (2019). In this research, however, she used 64 variables de- 
scribing 17 goals of the 2030 Agenda. Her research shows that countries located in Northern and Western Europe have achieved much better results in terms of the ability to compete sustainably than do the countries of Eastern and Southern Europe. Northern and Western countries are those indicated as the most economically developed, while at the same time the most competitive in the entire European Union. Compared to other results, e.g. research by Popescu et al. (2017), the authors used the Hierarchical Clustering methodology, aiming at evaluating the global competitiveness and performance of the EU countries in terms of a sustainable development model using four indices: HDI, EPI, GCI and GDP per capita.

\section{CONCLUSION}

Looking for modern indicators and global indices of economic growth, Europe, stimulating its competitiveness and innovation, currently uses the concept of sustainable development, to which many legal acts, political documents and development strategies refer to at all levels, from local to global, allowing to unlock its development and competitive potential.

Despite the growing popularity, the scope of employment of this concept in practical terms is small, and the effect is that no clear changes are observed in the implementation of the assumptions. It seems that the reason for its low level of implementation may be its complex and interdisciplinary character, which encompasses various dimensions: economic, social, environmental or spatial.

The significant diversity of living standards in the world is an important factor hindering the implementation of the concept of sustainable development. The challenges of this idea are more easily met by highly developed countries, which is largely due to the greater social awareness of their inhabitants. Sustainable development is a complex phenomenon due to the wide range of factors that cover it. In the literature on the subject, there is no single measure of sustainable development that could involve everything the concept "sustainability" means (Ciegis et al., $2009 \mathrm{~b})$. This encouraged the authors to attempt to develop such a measure and compare the EU countries in terms of the level of implementation of all sustainable development goals. Liu et al. (2017) pointed to the fact that different sustainability indicators tend to reflect different or even converse outcomes in terms of countries and need to clarify whether these indicators are actually coherent with each other.

The research results obtained by the authors show strong spatial differentiation of European countries in terms of the achieved indicator of sustainable development. The countries of Western and Northern Europe are higher in the rankings while the countries of Southern and Eastern Europe are lower.

For the EU to be strong, competitive, secure and rich, and for the cohesion policy to be implemented, every country must pursue an active and responsible policy to achieve sustainable development goals. The EU is a community of countries that are different, but are also aware of the challenges they must face. Therefore, it is so important for researchers to monitor and analyze achievements in implementing sustainable development assumptions. In the future, this will allow not only to assess the progress of the respective EU countries in achieving the objectives of 
sustainable development, but also to conduct an appropriate policy to support activities aimed at reaching its goals. It means to develop the key indicators of sustainable development in the context of SDG: quality education, environment protection, development of science and research, eco-innovation, modern technologies and digitalization in various areas of economic systems.

However, this research and our findings also have some limitations as for the year 2018, and mainly, previous years for the reason of a lack of data unavailability, a lack of data of some sustainable goals in measuring a synthetic way of individual countries.

It seems that in the future research, it would be interesting to analyze sustainable development of the EU countries taking into account the challenges of competitiveness in a longer time horizon as well as assess these changes over time. We would like to compare our findings with the findings of the newest empirical studies and investigate the development trajectory of the EU countries at least three years by extending the multidimensional methods used, enlarging the dataset and a cross-sectional analysis of studied goals of sustainable development and sustainable competitiveness.

\section{Acknowledgements}

This contribution was supported by the research grant VEGA No. 1/0279/19 "Model approaches to increase performance and competitiveness in the European area in the context of sustainable development," funded by the Ministry of Education, Science, Research and Sport of the Slovak Republic.

\section{References}

1. Balcerzak, A. P. (2015). Europe 2020 Strategy and Structural Diversity Between Old and New Member States. Application of Zero Unitarization Method for Dynamic Analysis in the Years 2004-2013. Economics and Sociology, 8 (2), 190-210. http://dx.doi.org/10.14254/2071-789X.2015/8-2/14

2. Balkytè, A., \& Tvaronavičienè, M. (2010). Perception of competitiveness in the context of sustainable development: Facets of "sustainable competitiveness". Journal of Business Economics and Management, 11 (2), 341-365. https://doi.org/10.3846/jbem.2010.17

3. Barbier, E. B. (2016). Sustainability and development. Annual Review of Resource Economics, 8, 261-280. https://doi.org/10.1146/annurev-resource-100815-095227

4. Barbier, E. B., \& Burgess, J.C. (2019). Sustainable development goal indicators: Analyzing trade-offs and complementarities. World Development, 122, 295-305. https://doi.org/10.1016/j.worlddev.2019.05.026

5. Bartłomowicz, T., \& Cheba, K. (2017). Multidimensional comparative analysis of European Union countries in the field of sustainable development. Research Papers of Wrockaw University of Economics, 476, 118-126. https://doi.org/10.15611/pn.2017.476.11

6. Boons, F., Montalvo, C., Quist, J., \& Wagner, M. (2013). Sustainable innovation, business models and economic performance: An overview. Journal of Cleaner Production, 45, 1-8. https://doi.org/10.1016/j.jclepro.2012.08.013

7. Borys, T. (2011). Zrównoważony rozwój - jak rozpoznać ład zintegrowany. Problemy Ekorozwoju, 6 (2), 75 - 81. 
8. Busłowska, A. (2014). Realizacja celów zrównoważonego rozwoju w „Strategii rozwoju społeczno - gospodarczego Polski Wschodniej do roku 2020”. Oeconomia Copernicana, 5 (1), 43-60. https://doi.org/10.12775/OeC.2014.003

9. Cheba, K. (2019). Zrównoważona międzynarodowa konkurencyjność krajów UE. Studium teoretyczno-empiryczne. Warszawa: CeDeWu.

10. Cheba, K., \& Szopik-Depczyńska, K. (2017). Multidimensional comparative analysis of the competitive capacity of the European Union countries and geographical regions. Oeconomia Copernicana, 8 (4), 487-504. https://doi.org/10.24136/oc.v8i4.30

11. Ciegis, R., Ramanauskiene, J., \& Martinkus, B. (2009a). The Concept of Sustainable Development and Its use for Sustainability Scenarios. Engineering Economics, 2, $28-37$.

12. Ciegis, R., Ramanauskiene, J., \& Startiene, G. (2009b). Theoretical Reasoning of the Use of Indicators and Indices for Sustainable Development Assessment. Engineering Economics, 3, $33-40$.

13. Colglazier, W. (2015). Sustainable development agenda: 2030. Science, 349 (6252), 1048-1050. https://doi.org/10.1126/science.aad2333

14. Cyrek, M., \& Fura, B. (2019). Employment for sustainable development: sectoral efficiencies in EU countries. Social Indicators Research, 143, 277-318. https://doi.org/10.1007/s11205-018-1970-8

15. Dobrovic, J., Gallo, P., Mihalcova, B., Stofova, L., \& Szaryszova, P. (2018). Competitiveness Measurement in Terms of the Europe 2020 Strategy. Journal of Competitiveness, 10 (4), 21-37. https://doi.org/10.7441/joc.2018.04.02

16. Elliott, J. A. (2006). An introduction to sustainable development (3rd ed.). London and New York: Routledge.

17. European Commission. (2016). Next steps for a sustainable European future: European action for sustainability. https://eur-lex.europa.eu/legal-content/EN/ TXT/?uri $=\mathrm{COM} \% 3 \mathrm{~A} 2016 \% 3 \mathrm{~A} 739 \% 3 \mathrm{AFIN}$

18. Eurostat database. Sustaible development indicators. Retreived from: https://ec.europa.eu/ eurostat/web/sdi/main-tables

19. Fura, B., \& Wang, Q. (2017). The level of socioeconomic development of EU countries and the state of ISO 14001 certification. Quality \& Quantity, 51 (1), 103-119. https://doi.org/10.1007/s11135-015-0297-7

20. Gong, M., Simpson, A., Koh, L., \& Tan, K. H. (2018). Inside out: The interrelationships of sustainable performance metrics and its effect on business decision making: Theory and practice. Resources, Conservation and Recycling, 128, 155-166.

https://doi.org/10.1016/j.resconrec.2016.11.001

21. Grzebyk, M., \& Stec, M. (2015). Sustainable development in EU countries: concept and rating of levels of development. Sustainable Development, 23 (2), 110-123.

https://doi.org/10.1002/sd.1577

22. Hollanders, H. (2019). European Innovation Scoreboard 2019 - Methodology Report. https:// ec.europa.eu 
23. Kološta, S., Král, P., \& Flaška F. (2019). Alternative measures of macroeconomic imbalances in the EU-design and verification. E+M Economics and Management, 22 (1), 36-53. https://doi.org/10.15240/tul/001/2019-1-003

24. Kukuła, K., \& Bogocz, D., (2014). Zero Unitarization Method and its Application in Ranking Research in Agriculture. Economic and Regional Studies, 7 (3), 5-13.

25. Lapinskiene, G. (2011). The analysis of the relationship between the sustainable development and competitiveness in the European countries. Intellectual Economics, 5 (3), 434-444.

26. Liu, G., Brown, M. T., \& Casazza, M. (2017). Enhancing the Sustainability Narrative through a Deeper Understanding of Sustainable Development Indicators. Sustainability, 9, 1-19. https://doi.org/10.3390/su9061078

27. Marková, V., Lesníková, P., Kaščáková, A., \& Vinczeová, M. (2017). The present status of sustainability concept implementation by businesses in selected industries in the Slovak Republic. E+M Economics and Management, 20 (3), 101-117. https://dx.doi.org/10.15240/tul/001/2017-3-007

28. Mashokhida A., Khabibovich A. A., Pálka P., \& Shakhlo R. (2018). The competitiveness and sustainable economic development of Tajikistan regions. Journal of Competitiveness, 10 (1), 73-88. https://dx.doi.org/10.7441/joc.2018.01.05

29. Meadowcroft, J. (2007). National sustainable development strategies: features, challenges and reflexivity. European Environment, 17 (3), 152-167.

30. Mikušová, M. (2017). To be or not to be a business responsible for sustainable development? Survey from small Czech businesses. Economic Research, 30 (1), 1318-1338. https://doi.org/10.1080/1331677X.2017.1355257

31. Momete, D. C. (2016). Rational development as a sustainable progress welfare vector: a crosscountry analysis. Sustainable Development, 25 (3), 189-199. https://doi.org/10.1002/sd.1645

32. Płachciak, A. (2010). Sustainable Development in Postmodern Society. Economics \& Sociology, 3 (2), 86-91.

33. Popescu, G. H., Sima, V., Nica, E., \& Gheorghe, I. G. (2017). Measuring Sustainable Competitiveness in Contemporary Economies - Insights from European Economy. Sustainability, 9 (7), 1-26. https://doi.org/10.3390/su9071230

34. Rhouma, A. B. (2010). Sustainable value in Europe: sustainability performance of the Czech Republic versus the Europe of fifteen. E+M Economics and Management, 4, 16-29.

35. Simionescu, M., Lazányi, K., Sopková, G., Dobeš, K., \& Balcerzak, A. P. (2017). Determinants of Economic Growth in V4 Countries and Romania. Journal of Competitiveness, 9 (1), 103-116. https://doi.org/10.7441/joc.2017.01.07

36. Škare, M., Kostelić, K. \& Jozičić, K. (2013). Sustainability of Employee Productivity as a Presumption of Sustainable Business. Economic Research-Ekonomska Istraživanja, 26 (sup1), 311-330. https://doi.org/10.1080/1331677X.2013.11517654

37. Stec, M., Filip, P., Grzebyk, M., \& Pierścieniak, A. (2014). Socio-economic development in EU member states - concept and classification. Engineering Economics, 25 (5), 504-512. https://doi.org/10.5755/j01.ee.25.5.6413 
38. Steurer, R., \& Hametner, M. (2013). Objectives and indicators in sustainable development strategies: similarities and variances across Europe. Sustainable Development, 21 (4), 224-241. https://doi.org/10.1002/sd.501

39. Sustainable development in the European Union. Monitoring report on progress towards the SDGS in AN EU context, 2017, Edition, EU 2017.

40. Sutopo, B., Kot, S., Adiati, A. K., \& Lina, N. (2018). Sustainability Reporting and Value Relevance of Financial Statements. Sustainability, 10 (3), 2-14. https://doi.org/10.3390/su10030678

41. Wskaźniki zrównoważonego rozwoju Polski. (2011). Katowice: GUS.

42. Taylor, B. (2014). Who wants to give forever? Giving meaning sustainability in development. Journal of International Development, 26 (8), 1181-1196. https://doi.org/10.1002/jid.3033

43. Ulewicz, R., \& Blaskova, M. (2018). Sustainable development and knowledge management from the stakeholders' point of view. Polish Journal of Management Studies, 18 (2), 363-374. https://doi.org/10.17512pjms.2018.18.2.29

44. United Nations Development Programme. (2018). Human development indices and indicators: 2018 Statistical update. http://hdr.undp.org/sites/default/files/ hdr2018_technical_notes.pdf

45. Zakrzewska, B. (2019). Zrównoważony rozwój a jakość życia. Organizacja i Zarz̨adz̧anie, 22 (4), 38-41. https://doi.org/10.24136/atest.2019.113

46. Zielińska, A. (2011). Applying Multidimensional Comparative Analysis for the Assessment of the Concept Realization of Sustainable Development for the Protected Areas. Economics \& Sociology, 4 (1), 87-96. https://doi.org/10.14254/2071-789X.2011/4-1/9

\section{Contact information:}

Associate Professor Dana Kiselakova, PhD.

University of Presov in Presov

Faculty of Management

Department of Finance

Slovakia

E-mail:dana.kiselakova@unipo.sk

ORCID: 0000-0001-5662-5809

Associate Professor Matgorzata Stec

University of Rzeszón

Institute of Economics and Finance

Poland

E-mail:malgorzata.a.stec@gmail.com

ORCID: 0000-0003-0185-4510

Associate Professor Mariola Grzebyle.

University of Rzeszón

Institute of Economics and Finance

Poland 
E-mail:mgrzebyk6@gmail.com

ORCID: 0000-0003-1107-0250

Beata Sofrankova, PhD.

University of Presov in Presov

Faculty of Management

Department of Finance

Slovakia

E-mail: beata.sofrankova@unipo.sk

ORCID: 000-0001-9766-0467 


\section{APPENDIX}

Tab. 2 - The values of synthetic measures of the EU countries for individual sustainable development goals. Source: own research

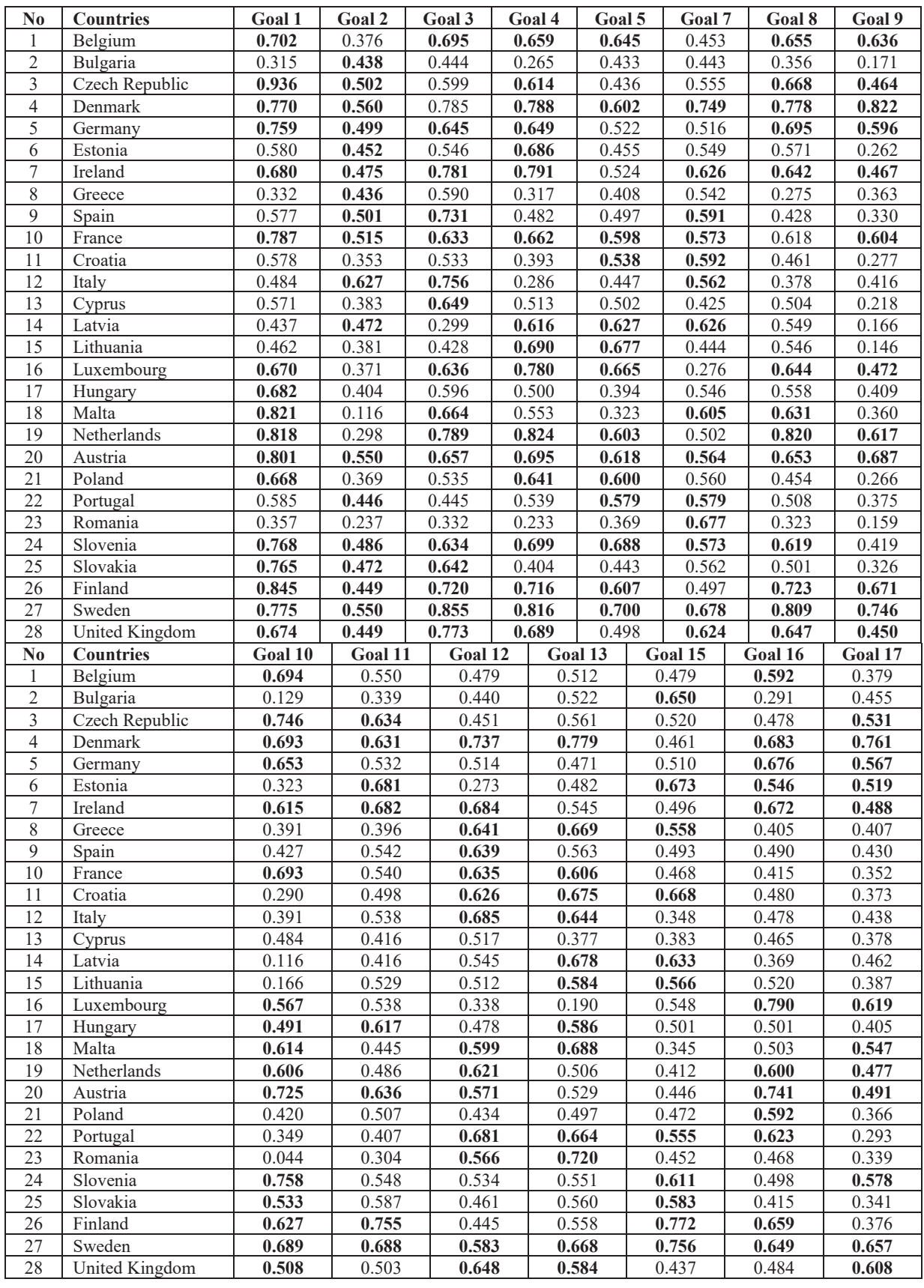

